\title{
HUBUNGAN ANTARA DENSITAS ENERGI DAN KUALITAS DIET DENGAN INDEKS MASSA TUBUH (IMT) PADA REMAJA
}

\author{
Ulfah Puspita Dewi, Fillah Fithra Dieny ${ }^{*}$ \\ Program Studi Ilmu Gizi Fakultas Kedokteran Universitas Diponegoro \\ J1.Dr.Sutomo No.18, Semarang, Telp (024) 8453708, Email : gizifk@ undip.ac.id
}

\begin{abstract}
Background: Low diet quality was associated with consumed high energy density food that directly contribute to the increased total energy intake and impacts increased Body Mas Index (BMI). The aimed of this study to analyzed association of energy density and diet quality with BMI (Body Mass Indexs) in adolescents.

Method: Observational research with cross sectional design, setting of this study was in senior high school 9 Semarang with 71 adolescents ages 16-18 are selected by simple random sampling. Data included identity samples, Body Mass Index (BMI), energy density, diet quality, and physical activity. BMI was obtained from calculated Zscore based BMI/U, energy density was measured by $3 \times 24$ hours recall, diet quality was measured DQI-I (Diet Quality indexs International) and physical activity was measured IPAQ (International Physical Activity Questionnaire). Data were analyzed by rank spearman.

Result: Consumed high energy density food was higher in women (32,4\%) than men (5,9\%). In men 8,8\% classified high diet quality and women 100\% classified low diet quality. Adolescent obesity and overweight 35,2\% and higher in women $(37,8 \%)$ than men $(32,3 \%)$. There was significant associated between diet quality with energy density $(r=$ -0,502; $p=0,000)$. There was significant associated between energy density with BMI $(r=0,569 ; p=0,000)$. However, there was no associated physical activity with BMI ( $r=-0,194 ; p=0,106)$.

Conclusion: Adolescents were consumed more low energy density food (fruits and vegetables) had a better diet quality and lower BMI than adolescents were consumed high energy density food (fat). Low diet quality association with consumed more high energy density food and impact increased BMI.
\end{abstract}

Keyword: Quality diet; energy density; body mass indexs; adolecents

\begin{abstract}
ABSTRAK
Latar Belakang : Kualitas diet rendah dikaitkan dengan konsumsi makanan berdensitas energi tinggi yang secara langsung berkontribusi dalam peningkatan asupan energi total dan berakibat pada peningkatan Indeks Massa Tubuh (IMT). Penelitian ini bertujuan untuk menganalisis hubungan antara densitas energi dan kualitas diet dengan IMT (Indek Massa Tubuh) pada remaja.

Metode : Penelitian observasional dengan pendekatan cross sectional, bertempat di SMA N 9 Semarang dengan jumlah sampel 71 remaja usia 16-18 tahun yang dipilih dengan simple random sampling. Data yang dikumpulkan meliputi identitas sampel, Indeks Massa Tubuh (IMT), densitas energi, kualitas diet, dan aktisfitas fisik. IMT diperoleh dari perhitungan Z-score berdasarkan BMI/U, densitas energi menggunakan recall $3 \times 24$ jam, kualitas diet menggunakan formulir DQI-I (Diet Quality indexs International), dan aktifitas fisik menggunakan kuisioner IPAQ (International Physical Activity Questionnaire). Data dianalisis dengan uji rank spearman.

Hasil : Konsumsi makanan berdensitas energi tinggi lebih banyak pada perempuan $(32,4 \%)$ dibandingkan laki-laki (5,9\%). Kualitas diet pada laki-laki 8,8\% tergolong tinggi sedangkan pada perempuan 100\% tergolong rendah. Gizi lebih (obesitas dan overweight) pada remaja sebesar 35,2\% dan secara umum lebih tinggi pada perempuan 37,8\% dibandingkan laki-laki 32,3\%. Ada hubungan signifikan antara kualitas diet dengan densitas energi $(r=-0,502$; $p=0,000)$. Ada hubungan signifikan antara densitas energi dengan IMT $(r=0,569 ; p=0,000)$. Namun, tidak terdapat hubungan antara aktifitas fisik dengan IMT ( $r=-0,194 ; p=0,106)$.

Simpulan : Remaja yang mengkonsumsi lebih banyak makanan berdensitas energi rendah (buah dan sayur) kualitas dietnya lebih baik dan IMT nya lebih rendah daripada remaja yang mengkonsumsi makanan berdensitas energi tinggi (sumber lemak). Kualitas diet rendah berhubungan dengan tingginya konsumsi makanan berdensitas energi tinggi yang dapat berdampak pada peningkatan IMT.
\end{abstract}

Kata kunci : Kualitas diet; densitas energi; indeks massa tubuh; remaja

\section{PENDAHULUAN}

Periode remaja adalah periode transisi dari anak-anak menuju dewasa yang perlu mendapat perhatian khusus karena pada periode ini rentan terjadi masalah gizi, baik gizi kurang maupun gizi lebih. Masalah gizi yang terjadi pada remaja dapat disebabkan perilaku gizi yang salah, yaitu pemenuhan kebutuhan zat gizi yang tidak sesuai dengan rekomendasi diet yang dianjurkan. ${ }^{1}$ 
Ketidaksesuaian pemenuhan zat gizi pada remaja dapat dipengaruhi oleh faktor lingkungan seperti teman sebaya dan media massa. Teman sebaya mempengaruhi pemilihan makanan, dimana tidak lagi didasarkan pada kandungan gizi tetapi sekadar bersosialisasi dan kesenangan supaya tidak kehilangan status. ${ }^{2}$ Media massa yang menayangkan berbagai macam iklan makanan juga mempengaruhi remaja dalam memilih dan mengkonsumsi makanan. ${ }^{2}$ Kedua faktor tersebut dapat berdampak pada perubahan pola makan remaja yaitu lebih memilih makanan praktis dan siap saji yang cenderung tinggi energi, rendah serat, dan rendah mikronutrien. ${ }^{3}$ Hal ini dapat mempengaruhi asupan energi menjadi berlebih, sehingga remaja rentan mengalami masalah gizi lebih terutama overweight dan obesitas. ${ }^{3}$

Berdasarkan data Riskesdas 2007 dan 2010 pada penduduk berusia di atas 15 tahun menunjukkan adanya peningkatan prevalensi obesitas dari $10,3 \%$ menjadi $19,1 \%$. ${ }^{4,5}$ Sedangkan di Jawa Tengah, prevalensi obesitas pada remaja usia di atas 15 tahun sebesar $17 \%$ dan secara umum obesitas lebih banyak dialami oleh perempuan $21,7 \%$ dibandingkan laki laki $11,5 \% .^{5}$

Ketidaksesuaian pemenuhan zat gizi berdasarkan rekomendasi diet dapat mempengaruhi kualitas diet. ${ }^{6}$ Kualitas diet penting untuk menilai asupan makan telah sesuai rekomendasi atau tidak. Apabila tidak sesuai dengan rekomendasi yang ditetapkan akan mempengaruhi status gizi. Penelitian di Inggris tahun 2009 menunjukkan individu dengan kualitas diet tinggi memiliki Indeks Massa Tubuh (IMT) yang lebih rendah daripada individu dengan kualitas diet rendah. ${ }^{6}$ Penelitian terhadap pola makan remaja Tunisia dan Turki menunjukkan hanya 38\% remaja Tunisia dan $1,9 \%$ remaja Turki memiliki kualitas diet yang memuaskan atau mengkonsumsi makanan sesuai rekomendasi diet. ${ }^{7,8}$

Kualitas diet yang rendah biasanya ditunjukan dengan konsumsi energi, gula dan lemak jenuh secara berlebih, tetapi rendah konsumsi padi-padian, buah dan sayur. ${ }^{9}$ Sedangkan kualitas diet yang bagus dikaitkan dengan tingginya konsumsi makanan dengan densitas energi rendah sepeti buah dan sayur, serta mencukupi kebutuhan makronutrien secara tepat, tidak kurang maupun berlebih. ${ }^{10}$ Beberapa penelitian di Amerika Serikat dan Inggris pada anak, remaja, dan dewasa membuktikan adanya hubungan antara kualitas diet dengan densitas energi makanan yang dikonsumsi yaitu semakin banyak konsumsi makanan dengan densitas energi tinggi, semakin rendah kualitas dietnya. ${ }^{11,12}$

Konsumsi makanan dengan densitas energi tinggi secara berlebih secara langsung dapat mempengaruhi peningkatan nilai IMT. Survey NHANES (1999-2004) pada remaja di US menunjukkan bahwa remaja yang mengkonsumsi makanan dengan densitas energi rendah memiliki IMT lebih rendah daripada remaja yang mengkonsumsi makanan dengan densitas energi tinggi. ${ }^{11} \mathrm{Hal}$ ini didukung oleh hasil penelitian di US yang menemukan bahwa remaja yang berat badannya normal, mengkonsumsi makanan dengan densitas energi lebih rendah daripada remaja yang obes. ${ }^{13}$ Fenomena konsumsi makanan dengan densitas energi tinggi seperti fast food dan minuman bergula telah menjadi kebiasaan dan trend bagi remaja di Amerika Serikat dan beberapa negara Asia. ${ }^{21}$ Hal ini dibuktikan $83 \%$ remaja berusia kurang dari 17 tahun mengunjungi restoran makanan cepat saji (fast food) setiap harinya. ${ }^{14}$

Berdasarkan latar belakang tersebut, maka tujuan penelitian ini untuk menganalisis hubungan antara kualitas diet dan densitas energi dengan Indeks Massa Tubuh (IMT) pada remaja.

\section{METODE}

Penelitian ini merupakan penelitian observasional dengan rancangan cross sectional dan termasuk lingkup gizi masyarakat. Penelitian dilaksanakan di SMA Negeri 9 Semarang pada bulan Juni 2013. Populasi pada penelitian ini adalah seluruh siswa-siswi kelas $\mathrm{X}$ dan $\mathrm{XI}$ sejumlah 731 orang. Berdasarkan perhitungan sampel menggunakan rumus estimasi proporsi didapatkan subjek minimal adalah 64 subjek dan dalam penelitian ini diperoleh 71 subjek. Metode pengambilan sampel menggunakan Simple Random Sampling yang sebelumnya telah dipilih sesuai kriteria inklusi yakni tidak sakit atau absen selama proses pengambilan data, tidak sedang menjalani diet untuk penurunan berat badan dan tidak sedang menjalani diet karena penyakit tertentu.

Data yang dikumpulkan dalam penelitian adalah identitas sampel, Indeks Massa Tubuh (variabel terikat), densitas energi makanan dan kualitas diet (variabel bebas), serta aktisfitas fisik (variabel perancu). Indeks Massa Tubuh (IMT) adalah gambaran keadaan gizi seseorang yang didapatkan dengan cara membagi berat badan $(\mathrm{kg})$ dengan kuadrat tinggi badan (meter) kemudian dikonversikan ke dalam nilai z-score IMT/U untuk 
remaja laki-laki dan perempuan usia 5-19 tahun menggunakan program WHO Anthro Plus 2007. Status gizi dikategorikan menjadi obesitas $>+2$ SD, kelebihan berat badan (overweight) >+1SD, normal -2 SD- +1 SD, kurus (thinness) $<-2 \mathrm{SD}$, dan sangat kurus (severe thinness) $<-3 \mathrm{SD} .{ }^{15}$ Berat badan ditimbang dengan timbangan digital yang memiliki kapasitas $150 \mathrm{~kg}$ dan ketelitian $0,1 \mathrm{~kg}$, sedangkan tinggi badan diukur dengan microtoise yang memiliki kapasitas $200 \mathrm{~cm}$ dan ketelitian 0,1 $\mathrm{cm}$.

Konsumsi energi adalah energi yang masuk dalam tubuh yang berasal dari minuman dan makanan. Total konsumsi energi diperoleh dari makanan dan minuman yang dikonsumsi sehari melalui dietary recall selama $3 \times 24$ jam pada 2 hari aktif sekolah dan 1 hari libur. Perhitungan densitas energi makanan diperoleh melalui total energi makanan sehari dibagi berat makanan dan perhitungan densitas energi minuman diperoleh melalui total energi minuman sehari dibagi berat minuman. Densitas energi pada laki laki dikategorikan menjadi tiga yaitu rendah apabila nilai densitas energi $<1,7 \mathrm{kkal} / \mathrm{g}$, sedang apabila $1,7-2,1 \mathrm{kkal} / \mathrm{g}$, dan tinggi apabilan $>2,1 \mathrm{kkal} / \mathrm{g}$. Sedangkan untuk perempuan dikategorikan rendah apabila nilai densitas energi $<1,6 \mathrm{kkal} / \mathrm{g}$, sedang apabila 1,6-2,0 kkal/g, dan tinggi apabilan > 2,0 $\mathrm{kkal} / \mathrm{g} .{ }^{16}$

Kualitas diet merupakan penilaian konsumsi makanan yang terdiri dari 4 komponen utama yaitu variasi, kecukupan (adequacy), moderasi dan keseimbangan keseluruhan (overall balance) berdasarkan rekomendasi diet/ pedoman gizi dengan menggunakan formulir DQI-I (Diet Quality indexs International). Kualitas diet diklasifikasikan menjadi 2 kategori yaitu rendah apabila nilai $\leq 60$ dan tinggi apabila nilai $>60 .{ }^{17}$
Aktifitas fisik merupakan jenis, frekuensi \& durasi aktifitas fisik yang dilakukan subjek selama 7 hari menggunakan kuisioner IPAQ (International Physical Activity Questionnaire) diklasifikasikan menjadi 3 kategori yaitu rendah apabila $<600$ MET-menit/minggu, sedang apabila 600-2999 MET-menit/minggu, dan tinggi apaila $\geq 3000$ MET-menit/minggu. ${ }^{18}$

Pengolahan dan analisis data dilakukan dengan program komputer Statistical Package for Social Science (SPSS). Analisis univariat digunakan untuk mendeskripsikan masing-masing variabel. Analisis bivariat digunakan untuk mengetahui hubungan antara kualitas diet dengan densitas energi, hubungan antara densitas energi dengan IMT, dan hubungan antara aktifitas fisik dengan IMT pada remaja. Uji normalitas menggunakan Kolmogorov-Smirnov dan uji hubungan menggunakan Rank Spearman.

\section{HASIL \\ Karakteristik Subjek Penelitian}

Jumlah total subjek penelitian sebanyak 71 orang yang terdiri dari 34 remaja laki-laki dan 37 remaja perempuan usia 16-18 tahun. Rerata z-score IMT/U pada laki-laki $0,08 \mathrm{SD} \pm 1,20$ lebih rendah dibandingkan perempuan $0,25 \mathrm{SD} \pm 1,04$. Rerata asupan energi pada laki-laki lebih tinggi $(1837,5 \mathrm{kkal} \pm 310,1) \quad$ daripada perempuan (1318kkal $\pm 244,5)$, namun rerata densitas energi makanan yang dikonsumsi pada laki-laki $(1,68$ $\mathrm{kkal} / \mathrm{g} \pm 0,23)$ lebih rendah rendah daripada perempuan $(1,86 \pm 0,29)$. Kualitas diet pada lakilaki lebih tinggi $(51,78 \pm 5,85)$ daripada perempuan $(45,45 \pm 4,8)$ dan rerata aktifitas fisik juga lebih tinggi pada laki-laki (2416,7MET$\mathrm{min} /$ minggu $\pm 614,0)$ dibandingkan perempuan

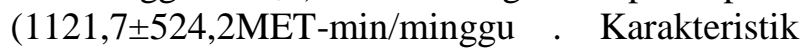
subjek selengkapnya dapat dilihat pada tabel 1 .

Tabel 1. Karakteristik nilai IMT, z-score IMT/U, densitas energi, kualitas diet dan skor aktifitas fisik berdasarkan jenis kelamin

\begin{tabular}{lcccccc}
\hline Karakteristik subjek & \multicolumn{3}{c}{ Laki-laki $(\mathrm{n}=34)$} & \multicolumn{3}{c}{ Perempuan $(\mathrm{n}=37)$} \\
\cline { 2 - 7 } & Min & Maks & Rerata \pm SD & Min & Maks & Rerata \pm SD \\
\hline IMT $\left(\mathrm{kg} / \mathrm{cm}^{2}\right)$ & 17,1 & 29,90 & $21,8 \pm 3,40$ & 17,30 & 33,30 & $22,29 \pm 3,8$ \\
Z-score IMT/U(SD) & $-2,28$ & 2,28 & $0,08 \pm 1,20$ & $-1,51$ & 2,61 & $0,22 \pm 1,04$ \\
Asupan energi (kkal) & 1317 & 2859,3 & $1837,5 \pm 310,1$ & 998,3 & 1923 & $1318 \pm 244,5$ \\
Densitas Energi(kkal/g) & 1,29 & 2,25 & $1,68 \pm 0,23$ & 1,30 & 2,62 & $1,86 \pm 0,29$ \\
Kualitas Diet(skor DQI-I) & 38 & 66,33 & $51,78 \pm 5,85$ & 31,67 & 56,33 & $45,45 \pm 4,8$ \\
Skor Aktifitas Fisik & 1380 & 3290 & $2416,7 \pm 614,0$ & 559 & 2598 & $121,7 \pm 524,2$ \\
(MET-min/minggu) & & & & & & \\
\hline
\end{tabular}


Distribusi Frekuensi Densitas Energi, Kualitas Diet, Dan Aktifitas Fisik

Pada penelitian ini, subjek yang mengalami gizi lebih (obesitas dan overweight) sebesar $35,2 \%$ dan secara umum lebih banyak dialami oleh perempuan 37,8\% dibandingkan lakilaki $32,3 \%$. Konsumsi makanan dengan densitas energi tinggi lebih banyak terjadi pada perempuan $(32,4 \%)$ dibandingkan laki-laki $(5,9 \%)$.

Tabel 2. Distribusi frekuensi densitas energi, kualitas diet, dan aktifitas fisik berdasarkan jenis kelamin

\begin{tabular}{|c|c|c|c|c|c|c|}
\hline \multirow[t]{2}{*}{ Karakteristik } & \multicolumn{2}{|c|}{ Laki-laki (n=34) } & \multicolumn{2}{|c|}{ Perempuan $(n=37)$} & \multicolumn{2}{|c|}{ Total } \\
\hline & $\mathbf{n}$ & $\%$ & $\mathbf{n}$ & $\%$ & $\mathbf{n}$ & $\%$ \\
\hline \multicolumn{7}{|l|}{ IMT } \\
\hline Obesitas & 1 & 2,9 & 2 & 5,4 & 3 & 4,2 \\
\hline Overweight & 10 & 29,4 & 12 & 32,4 & 22 & 31,0 \\
\hline Normal & 22 & 64,7 & 23 & 62,2 & 45 & 63,4 \\
\hline Kurus & 1 & 2,9 & 0 & 0 & 1 & 1,4 \\
\hline Sangat kurus & 0 & 0 & 0 & 0 & 0 & 0 \\
\hline \multicolumn{7}{|c|}{ Densitas Energi } \\
\hline Rendah & 22 & 64,7 & 8 & 21,6 & 30 & 42,3 \\
\hline Sedang & 10 & 29,4 & 17 & 45,9 & 27 & 38,0 \\
\hline Tinggi & 2 & 5,9 & 12 & 32,4 & 14 & 19,7 \\
\hline \multicolumn{7}{|l|}{ Kualitas Diet } \\
\hline Rendah & 31 & 91,2 & 37 & 100 & 68 & 95,8 \\
\hline Tinggi & 3 & 8,8 & 0 & 0 & 3 & 4,2 \\
\hline \multicolumn{7}{|l|}{ Aktifitas Fisik } \\
\hline Rendah & 0 & 0 & 5 & 13,5 & 5 & 7,0 \\
\hline Sedang & 23 & 67,6 & 32 & 86,5 & 55 & 77,4 \\
\hline Tinggi & 11 & 32,4 & 0 & 0 & 11 & 15,6 \\
\hline
\end{tabular}

Sebagian besar kualitas diet pada laki-laki dan perempuan tergolong rendah. Sebesar $8,8 \%$ remaja laki-laki memliki kualitas diet yang tinggi, tetapi pada semua subjek perempuan kualitas dietnya $100 \%$ rendah. Tingkat aktifitas fisik tinggi hanya terjadi pada remaja laki-laki $32,4 \%$, sedangkan remaja perempuan berada pada tingkat aktifitas rendah dan sedang (tabel 2).

Distribusi frekuensi IMT (Indeks Massa Tubuh)
Subjek dengan obesitas dan overweight lebih banyak mengkonsumsi makanan dengan densitas energi tinggi $(71,4 \%)$ daripada subjek yang IMT nya normal $(28,6 \%)$. Sebagian besar kualitas diet pada semua subjek tergolong rendah $(95,8 \%)$, namun kualitas diet yang tinggi hanya ditemukan pada subjek dengan IMT normal $(9,2 \%)$. Subjek dengan gizi lebih memiliki tingkat aktifitas fisik lebih rendah sebesar $71,1 \%$ dibandingkan subjek dengan IMT normal sebesar $20,0 \%$.

Tabel 3. Distribusi frekuensi IMT (Indeks Massa Tubuh) berdasarkan densitas energi, kualitas diet dan aktifitas fisik

\begin{tabular}{|c|c|c|c|c|c|c|c|c|c|c|}
\hline \multirow[t]{3}{*}{ Karakteristik } & \multicolumn{10}{|c|}{ IMT (Indeks Massa Tubuh) } \\
\hline & \multicolumn{2}{|c|}{ Obesitas } & \multicolumn{2}{|c|}{ Overweight } & \multicolumn{2}{|c|}{ Normal } & \multicolumn{2}{|c|}{ Kurus } & \multicolumn{2}{|c|}{ Total } \\
\hline & $\mathrm{n}$ & $\%$ & $\mathbf{n}$ & $\%$ & $\mathbf{n}$ & $\%$ & $\mathbf{n}$ & $\%$ & n & $\%$ \\
\hline \multicolumn{11}{|l|}{ Densitas } \\
\hline Energi & 0 & 0 & 1 & 3,3 & 29 & 96,7 & 0 & 0 & 9 & 42,3 \\
\hline Rendah & 1 & 3,7 & 13 & 48,1 & 12 & 44,4 & 1 & 3,7 & 51 & 38,0 \\
\hline Sedang & 2 & 14,3 & 8 & 57,1 & 4 & 28,6 & 0 & 0 & 11 & 19,7 \\
\hline \multicolumn{11}{|l|}{ Tinggi } \\
\hline Total & 3 & 4,2 & 22 & 31,0 & 45 & 63,4 & 1 & 1,4 & 71 & 100 \\
\hline \multicolumn{11}{|l|}{ Kualitas Diet } \\
\hline Rendah & 3 & 4,4 & 22 & 32,4 & 42 & 61,8 & 1 & 1,5 & 58 & 95,8 \\
\hline Tinggi & 0 & 0 & 0 & 0 & 3 & 100 & 0 & 0 & 3 & 9,2 \\
\hline
\end{tabular}




\begin{tabular}{lcccccccccc}
\hline Total & 3 & 4,2 & 22 & 31,0 & 45 & 63,4 & 1 & 1,4 & 71 & 100 \\
\hline Aktifitas Fisik & & & & & & & & & & \\
Rendah & 1 & 11,1 & 3 & 60,0 & 1 & 20,0 & 0 & 0 & 5 & 7,0 \\
Sedang & 1 & 2,0 & 17 & 30,9 & 36 & 65,5 & 1 & 2,0 & 55 & 77,5 \\
Tinggi & 1 & 9,1 & 2 & 18,2 & 8 & 72,7 & 0 & 0 & 11 & 15,5 \\
\hline Total & 3 & 4,2 & 22 & 31,0 & 45 & 63,4 & 1 & 1,4 & 71 & 100 \\
\hline
\end{tabular}

Asupan Energi Dan Densitas Energi Makanan dan Minuman

Remaja laki-laki dan perempuan dengan asupan densitas energi rendah mempunyai rata-rata asupan energi total, energi dari makanan maupun energi dari minuman lebih rendah daripada subjek dengan densitas energi tinggi.

Tabel 4. Asupan energi dari makanan dan minuman pada laki-laki dan perempuan dengan densitas energi rendah, sedang, tinggi

\begin{tabular}{lcccccc}
\hline \multirow{2}{*}{$\begin{array}{c}\text { Energi makanan } \\
\text { dan minuman }\end{array}$} & \multicolumn{5}{c}{ Densitas energi } \\
\cline { 2 - 7 } & $\begin{array}{c}\text { Rendah } \\
(\mathrm{n}=22)\end{array}$ & $\begin{array}{c}\text { Sedang } \\
(\mathrm{n}=1\end{array}$ & $\begin{array}{c}\text { Tinggi } \\
(\mathrm{n}=2)\end{array}$ & $\begin{array}{c}\text { Rendah } \\
(\mathrm{n}=8)\end{array}$ & $\begin{array}{c}\text { Sedang } \\
(\mathrm{n}=1\end{array}$ & $\begin{array}{c}\text { Tinggi } \\
(\mathrm{n}=1\end{array}$ \\
& & $0)$ & & & $7)$ & $2)$ \\
\hline Energi total (kkal) & $1671 \pm 393$ & $1821 \pm 3$ & $1906 \pm 1$ & $1124 \pm 1$ & $1360 \pm 2$ & $1387 \pm 2$ \\
& & 57 & 57 & 33 & 19 & 80 \\
Energi & $1683 \pm 339$ & $1715 \pm 9$ & $1866 \pm 1$ & $1062 \pm 1$ & $1126 \pm 4$ & $1221 \pm 2$ \\
$\quad$ makanan(kkal) & & 7 & 03 & 71 & 10 & 42 \\
Energi & $121 \pm 50,4$ & $133 \pm 73$, & $157 \pm 56$, & $88 \pm \mathrm{q} 04$, & $137 \pm 92$, & $151 \pm 92$ \\
$\quad$ minuman(kkal) & & 5 & 9 & 4 & 3 & 4 \\
DE total (kkal/g) & $1,36 \pm 0,1$ & $1,57 \pm 0$, & $1,63 \pm 0$, & $1,42 \pm 0$, & $1,52 \pm 0$, & $1,74 \pm 03$ \\
DE & $1,53 \pm 0,1$ & 15 & 40 & 12 & 24 &, 6 \\
makanan(kkal/g & $0,34 \pm 0,2$ & $1,91 \pm 0$, & $2,19 \pm 0$, & $1,48 \pm 0$, & $1,81 \pm 0$, & $2,20 \pm 0$, \\
) & & 07 & 80 & 10 & 12 & 16 \\
DE & & $0,41 \pm 0$, & $0,36 \pm 0$, & $0,23 \pm 0$, & $0,44 \pm 0$, & $0,38 \pm 0$, \\
minuman(kkal/ & & 10 & 07 & 25 & 29 & 22 \\
ml) & & & & & & \\
\hline
\end{tabular}

dengan densitas energi rendah rata-rata mengkonsumsi makanan $235 \mathrm{kkal} / \mathrm{hari}$ dan 263 $\mathrm{kkal} / \mathrm{hari}$ lebih rendah daripada subjek dengan densitas energi tinggi (tabel 4). Densitas energi total yang dikonsumsi lebih banyak disumbangkan dari makanan.

\section{Skor Komponen DQI-I (Diet Quality Indexs} International)

Skor total dari DQI-I secara jelas lebih tinggi pada remaja laki-laki dibandingkan remaja perempuan. Skor pada semua komponen DQI-I (variasi, kecukupan, moderasi, keseimbangan keseluruhan) juga lebih tinggi pada remaja lakilaki dibandingkan remaja perempuan. Nilai yang didapat pada komponen kecukupan, moderasi, dan overall balance masih jauh dari range poin, hanya pada komponen kecukupan kelompok padi-padian dan kecukupan protein nilainya tidak terlalu rendah.

Tabel 5 . Perbandingan skor DQI-I berdasarkan komponen DQI-I laki-laki dan perempuan

\begin{tabular}{lcc}
\hline Komponen (skor range/poin) & Perempuan & Laki-laki \\
& $(37)$ & $(34)$ \\
\hline DQI-I, total (0-100) & $45,7 \pm 0,83$ & $51,7 \pm 1,00$ \\
Variasi (0-20) & $14,4 \pm 0,36$ & $14,5 \pm 0,54$ \\
Variasi semua kelompok makanan (0-15) & $10,7 \pm 0,28$ & $10,6 \pm 0,29$ \\
Variasi kelompok sumber protein (0-5) & $3,7 \pm 0,13$ & $4,1 \pm 0,14$ \\
Kecukupan (0-40) & $16,8 \pm 0,46$ & $17,5 \pm 0,71$
\end{tabular}


Kelompok sayuran (0-5)

Kelompok buah buahan (0-5)

Kelompok padi-padian (0-5)

Serat $(0-5)$

Protein (0-5)

Besi (0-5)

Kalsium (0-5)

Vitamin C (0-5)

Moderasi (0-30)

Total lemak (0-6)

Lemak jenuh (0-6)

Kolesterol (0-6)

Natrium (0-6)

Empty Calorie foods (0-6)

Keseimbangan keseluruhan (Overaall balance) (0-10)

Rasio makronutrien (KH:P:L) (0-6)

Rasio asam lemak (PUFA:MUFA:SFA) (0-4)

$\begin{array}{cc}0,8 \pm 0,11 & 0,9 \pm 0,11 \\ 0,7 \pm 0,17 & 0,7 \pm 0,20 \\ 4,2 \pm 0,12 & 4,8 \pm 0,09 \\ 1,5 \pm 0,09 & 2,1 \pm 0,12 \\ 4,2 \pm 0,11 & 4,2 \pm 0,22 \\ 1,7 \pm 0,11 & 2,8 \pm 0,26 \\ 1,6 \pm 0,10 & 1,7 \pm 0,13 \\ 1,8 \pm 0,12 & 2,5 \pm 0,72 \\ 13,5 \pm 0,48 & 14,5 \pm 0,74 \\ 1,4 \pm 0,20 & 2,4 \pm 0,19 \\ 1,0 \pm 0,21 & 1,0 \pm 0,16 \\ 4,3 \pm 0,27 & 3,7 \pm 0,27 \\ 5,3 \pm 0,22 & 5,9 \pm 0,06 \\ 1,5 \pm 0,18 & 2,7 \pm 0,56 \\ 1,5 \pm 0,19 & 2,4 \pm 0,21 \\ & \\ 1,0 \pm 0,14 & 2,1 \pm 0,21 \\ 0,4 \pm 0,11 & 0,3 \pm 0,09\end{array}$

$0,8 \pm 0,11$

$0,9 \pm 0,11$

$4,8 \pm 0,09$

$2,1 \pm 0,12$

$2,8 \pm 0,26$

$1,7 \pm 0,13$

$2,5 \pm 0,72$

$4,5 \pm 0,74$

$2,4 \pm 0,19$

$1,0 \pm 0,16$

$3,7 \pm 0,27$

$5,9 \pm 0,06$

$2,7 \pm 0,56$

$2,1 \pm 0,21$

$0,4 \pm 0,11$

Tabel 6. Skor komponen DQI-I berdasarkan kategori densitas energi rendah, sedang, tinggi

\begin{tabular}{lccc}
\hline & \multicolumn{3}{c}{ Densitas Energi } \\
\cline { 2 - 4 } & $\begin{array}{c}\text { Rendah } \\
(\mathrm{n}=30)\end{array}$ & $\begin{array}{c}\text { Sedang } \\
(\mathrm{n}=27)\end{array}$ & Tinggi $(\mathrm{n}=14)$ \\
\hline Komponen DQI- & & & \\
$\quad$ I & & & \\
Variasi & $14,5 \pm 3,2$ & $14,6 \pm 1,7$ & $13,7 \pm 3,1$ \\
Kecukupan & $17,5 \pm 4,5$ & $17,6 \pm 2,2$ & $15,7 \pm 2,8$ \\
Moderasi & $14,3 \pm 4,1$ & $13,8 \pm 3,2$ & $13,7 \pm 3,7$ \\
Overall Balance & $2,5 \pm 1,2$ & $1,6 \pm 0,95$ & $1,4 \pm 0,38$ \\
\hline
\end{tabular}

Subjek dengan asupan densitas energi tinggi memiliki rata-rata skor pada semua komponen DQI-I (variasi, kecukupan, moderasi, keseimbangan keseluruhan) lebih rendah dibandingkan subjek dengan densitas energi rendah. Terdapat tiga komponen DQI-I yang dapat mempengaruhi densitas energi makanan yaitu variasi, kecukupan, dan moderasi. Pada komponen variasi dan kecukupan terdiri dari pemenuhan semua sumber kelompok makanan (daging/unggas/ika/telur, produk susu/kacang, padi-padian, buah dan sayur) dan variasi makanan dari sumber protein (daging, unggas, ikan, produk susu, kacang-kacangan, telur). Jenis sumber makanan tersebut terdiri dari makanan densitas energi tinggi (sumber lemak, protein dan karbohidrat) dan rendah (sayur dan buah). Pada komponen moderasi terdiri dari kecukupan pemenuhan lemak yang merupakan sumber makanan dengan nilai densitas energi paling tinggi yaitu 9 kkal/g. Pada subjek dengan densitas energi tinggi memiliki skor lebih rendah pada ketiga komponen tersebut. Hal ini disebabkan subjek hanya mengkonsumsi sumber daging/unggas dan padi-padian, variasi sumber protein hanya berasal dari satu atau dua sumber yang berbeda setiap harinya dan jumlahnya melebihi rekomendasi maksimum yang dianjurkan. Selain itu, konsumsi buah dan sayur rendah, hanya satu sajian bahkan tidak sama sekali setiap harinya.

Rendahnya skor DQI-I menunjukkan bahwa subjek memiliki kebiasaan mengkonsumsi makanan yang tidak sesuai rekomendasi diet, melebihi atau kurang dari rekomendasi yang dianjurkan.

\section{Hubungan antara kualitas diet dengan densitas energi}

Terdapat hubungan negatif antara kualitas diet dengan densitas energi $r=-0,502$ dan $p=0,000$ $(p<0,005)$. Semakin tinggi kualitas diet, semakin rendah densitas energi makanan yang dikonsumsi. 


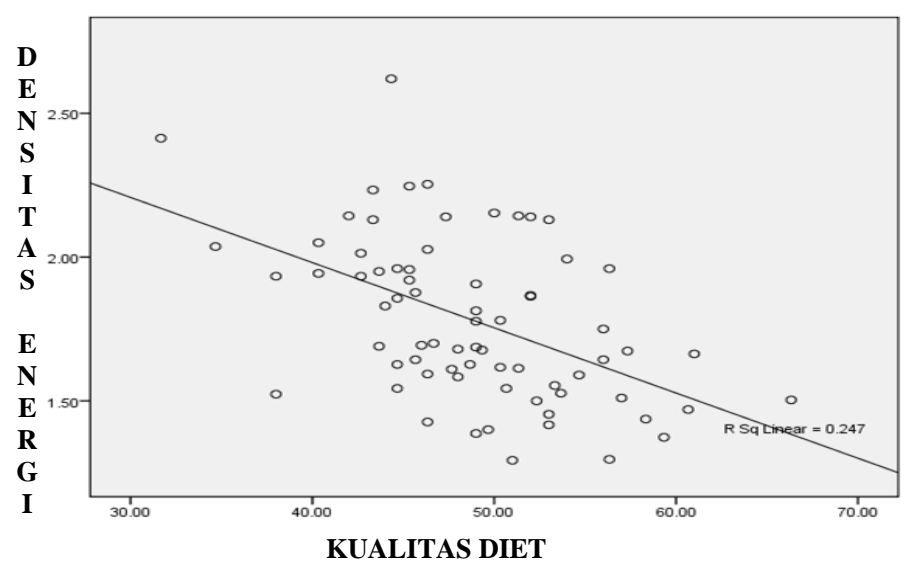

Hubungan antara densitas energi dan aktifitas fisik dengan IMT

Terdapat hubungan positif antara densitas energi dengan IMT pada remaja $r=0,569$ dan $\mathrm{p}=0,000 \quad(<0,005)$. Semakin tinggi konsumsi

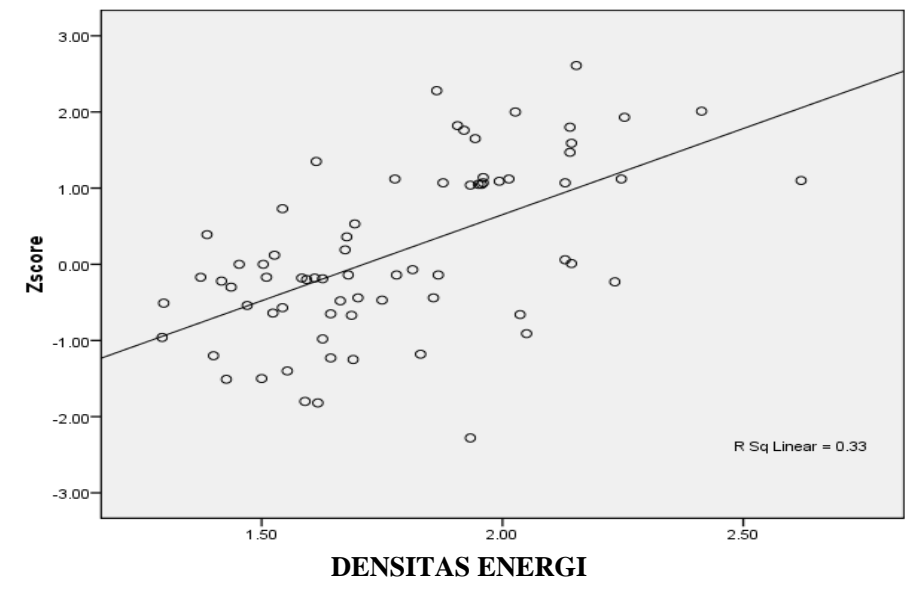

\section{PEMBAHASAN}

\section{Karateristik Subjek Penelitian}

Ditemukan prevalensi kejadian gizi lebih (obesitas dan overweight) pada penelitian ini sebesar 35,2\%. Prevalensi ini lebih tinggi dibandingkan penelitian yang dilakukan pada tahun 2012 di tempat yang sama yaitu dengan prevalensi $23,75 \% .{ }^{19}$ Secara umum gizi lebih lebih banyak dialami oleh perempuan $37,8 \%$ dibandingkan laki-laki 32,3\%. Prevalensi gizi kurang $1,4 \%$, jauh lebih rendah daripada masalah gizi lebih. Hal ini menunjukkan bahwa gizi lebih masih menjadi masalah pada remaja yang belum tertangani dengan baik dan prevalensinya masih cukup tinggi setiap tahunnya.

Subjek dalam penelitian ini berusia 16-18 tahun. Pada rentang usia tersebut, subjek termasuk dalam tahap remaja menengah (middle adolescence), dimana pengaruh teman sebaya dan media massa bepengaruh kuat dalam pemilihan makanan dengan densitas energi tinggi, semakin tinggi nilai IMT. Tidak ada hubungan secara langsung antara aktifitas fisik dengan IMT p 0,106 dan $-0,194$. makanan, terutama sumber makanan lemak dan gula. ${ }^{20}$ Hal ini dapat mempengaruhi asupan makanan menjadi berlebih, sehingga remaja rentan terhadap masalah gizi lebih.

Pada penelitian ini, rata-rata asupan energi makanan lebih tinggi pada laki-laki (1837,5 kkal) daripada perempuan (1318 kkal), namun rata-rata densitas energi makanan lebih tinggi pada perempuan $(1,86 \mathrm{kkalg} /)$ dibandingkan laki-laki $(1,68 \mathrm{kkal} / \mathrm{g})$. Sebanyak $32,4 \%$ perempuan juga mengkonsumsi makanan dengan densitas energi tinggi, lebih banyak dibandingkan laki-laki 5,9\%. Tingginya nilai densitas energi pada perempuan dikarenakan perempuan lebih banyak mengkonsumsi sumber makanan dengan densitas energi tinggi (banyak mengandung lemak atau gula yang ditambahkan dan kurang menggandung serat) seperti makanan yang digoreng, daging, es krim dan fast food, sehingga meningkatkan nilai densitas energi makanan. Pada laki-laki asupan 
terhadap sumber makanan dengan densitas energi rendah seperti buah dan sayur lebih tinggi dibandingkan perempuan, sehingga dapat menurunkan nilai kepadatan energi makanan. Konsumsi lemak secara berlebih menyebabkan peningkatkan nilai densitas energi makanan, sedangkan konsumsi cukup serat dapat menurunkan densitas energi makanan. ${ }^{21} \mathrm{Hal}$ inilah yang menyebabkan pada perempuan nilai densitas energinya lebih tinggi walaupun asupan energinya labih rendah dibandingkan laki-laki.

Pada penelitian ini, hanya $9,2 \%$ subjek yang memiliki kualitas diet tinggi dan semuanya berada pada subjek laki-laki, sedangkan pada perempuan $100 \%$ memiliki kualias diet rendah. Seperti halnya di turki yang hanya ada 1,9\% remaja yang memiliki kualitas diet memuaskan dan mengkonsumsi makanan sesuai rekomendasi diet yang dianjurkan. ${ }^{6}$ Hal ini menunjukkan bahwa kesadaran para remaja masih rendah dalam memenuhi kebutuhan gizi sesuai rekomendasi yang dianjurkan.

Secara umum aktifitas fisik lebih tinggi pada laki-laki dibandingkan perempuan. Sebanyak $32,4 \%$ subjek laki-laki memiliki tingkat aktifitas fisik tinggi, sedangkan pada perempuan hanya berada pada tingkat aktifitas fisik sedang dan rendah. Intensitas olah raga yang teratur pada lakilaki (sepakbola, basket, tenis dan fitnes secara teratur) sebanyak 2-3 kali/minggu menyebabkan tingkat aktifitasnya lebih tinggi dibandingkan perempuan.

\section{Asupan Energi Dan Densitas Energi Makanan Dan Minuman}

Remaja di kota besar sudah mengalami pergeseran pola makan dari pola makan tradisional ke pola makan barat. Pemilihan makanan tidak lagi didasarkan pada kandungan gizi, tetapi lebih banyak dipengaruhi oleh media massa dan sosialisasi antar teman sebaya. Remaja cenderung mengkonsumsi makanan dengan densitas energi tinggi yang biasanya tinggi kandungan karbohidrat sederhan dan lemak. ${ }^{22}$ Makanan tersebut cenderung memberikan rasa lezat dan harga murah sehingga banyak disukai. Konsumsi makanan dengan kepadatan energi tinggi (banyak mengandung lemak, gula dan kurang menggandung serat) secara berlebihan berkontribusi dalam peningkatan asupan energi total. Sedangkan konsumsi makanan dengan densitas energi rendah mampu menurunkan asupan energi total. ${ }^{23}$ Subjek dengan asupan makanan berdensitas energi rendah memiliki asupan energi total lebih rendah (235-263 kkal/hari lebih rendah) dibandingkan subjek dengan asupan makanan berdensitas energi tinggi.

Densitas energi lebih banyak disumbangkan dari makanan daripada minuman. Makanan padat seperti sereal dan padi-padian mengandung sedikit air dan tinggi energi menyumbang densitas energi lebih tinggi dibandingkan buah, dan sayur yang mengandung banyak air dan rendah energi. ${ }^{12}$ Minuman mengandung kadar air yang tinggi dan menyumbang lebih sedikit energi dan nutrisi sehingga tidak terlalu mempengaruhi nilai densitas energi, misalnya cola $500 \mathrm{ml}$ nilai densitas energinya $0,23 \mathrm{kkal} / \mathrm{ml}$.

\section{Skor Komponen DQI-I (Diet Quality Indexs International)}

Total skor DQI-I pada laki-laki lebih tinggi dibandingkan perempuan. Tetapi secara umum rerata keduanya mempunyai kualitas diet yang rendah. Rendahnya kualitas diet pada remaja perempuan disebabkan tingginya konsumsi sumber makanan berdensitas energi tinggi yaitu sumber lemak lebih dari $30 \%$ per hari. Selain itu, pada komponen kecukupan buah, sayur, protein nilainya juga jauh lebih rendah daripada laki-laki.

Terdapat empat komponen dalam penilaian DQI-I dan laki-laki mendapatkan skor yang lebih tinggi dibandingkan perempuan. Asupan serat pada laki-laki dan perempuan masih rendah dan jauh dari rekomendasi yang ditetapkan yaitu 20-30 g/hari, tetapi pada laki-laki skor yang didapat lebih tinggi sehinga mempengaruhi nilai densitas energi menjadi lebih rendah dan kualitas dietnya lebih baik. Serat dapat menurunkan nilai kepadatan energi, karena makanan yang tinggi serat biasanya tinggi kandungan air misalnya sayur dan buah. Pada komponen moderasi yang terdiri dari total asupan lemak, lemak jenih, kolesterol, natrium dan empty calory food (gula dan minyak) skor yang didapat masih rendah dan laki-laki tetap mendapatkan skor lebih tinggi. Rendahnya skor pada komponen moderasi dapat meningkatkan nilai densitas energi, karena makanan sumber lemak menyumbang nilai densitas energi sebesar 9 $\mathrm{kkal} / \mathrm{g}$, jauh lebih tinggi daripada serat yang hanya $1-1,5 \mathrm{kkal} / \mathrm{g}$. $^{24}$

Pada komponen overall balance yang terdiri dari rasio makronutrien (karbohidrat : lemak : protein) dan rasio asam lemak (PUFA : MUFA : SFA) laki-laki mendapatkan skor lebih tinggi. Tetapi secara umum menunjukkan bahwa semua subjek masih rendah dalam keseimbangan mengkonsumsi makanan sumber karbohidrat, lemak, dan protein. Hal ini sejalan dengan 
penelitian Nadia Gharib pada remaja di Bahrain dan Saudi arabia yang menemukan bahwa keseimbangan terhadap konsumsi sumber karbohidrat, lemak dan protein masih rendah. Meskipun rata-rata asupan energi siswa mendekati angka kecukupan gizi yang dianjurkan, namun sekitar 36-50\% siswa mengalami kelebihan energi yang berasal dari lemak total, lemak jenuh dan kolesterol. ${ }^{25}$

\section{Hubungan antara kualitas diet dengan densitas energi}

Pada penelitian ini disimpulkan bahwa kualitas diet seseorang mempengaruhi densitas energi makanan yang dikonsumsi. Semakin rendah kualitas diet, semakin tinggi asupan makanan dengan densitas energi tinggi. Semakin baik kualitas diet seseorang, semakin baik pula pemenuhan kebutuhan asupan sesuai rekomendasi diet yang dianjurkan. Subjek dengan kualitas diet tinggi mengkonsumsi buah dan sayur lebih banyak daripada subjek dengan kualitas diet rendah. Asupan sumber padi-padian dan sumber protein juga sesuai atau mendekati kecukupan serta lebih bervariasi setiap harinya. Selain itu, asupan terhadap sumber lemak hewani tidak lebih dari dua sajian setiap harinya. Sedangkan subjek dengan kualitas diet rendah lebih banyak mengkonsumsi sumber protein hewani (bersumber dari daging dan unggas) $\geq 2-3$ kali sajian/hari, minuman bergula $\geq$ $3 \mathrm{kali} /$ hari serta rendahnya konsumsi sumber buah dan sayur. Penelitian di US dan Perancis mengungkapkan bahwa kualitas diet yang baik dikaitkan dengan kecukupan terhadap asupan buah, sayur dan padi-padian serta membatasi sumber lemak jenuh yang berasal dari hewani. ${ }^{11,23} \mathrm{Hal}$ ini menunjukkan bahwa subjek dengan kualitas diet rendah lebih banyak mengkonsumsi makanan dengan densitas energi tinggi (lemak dan gula) dibandingkan dengan subjek dengan kualitas diet tinggi. Penelitian di Spanyol menunjukkan 10,2 \% subjek yang teratur mengkonsumsi makanan dengan densitas energi rendah memiliki kualitas diet yang lebih baik, asupannya tidak melebihi rekomendasi yang telah ditetapkan dan IMT nya lebih rendah daripada subyek yang mengkonsumsi makanan dengan densitas energi tinggi. ${ }^{12}$

\section{Hubungan antara densitas energi dengan IMT}

Subjek dengan IMT normal

mengkonsumsi makanan dengan densitas energi lebih rendah daripada subjek obesitas dan overweight. Hal ini sesuai dengan penelitian di Perancis yang mengungkapkan bahwa remaja yang memiliki berat badan normal mengkonsumsi makanan dengan densitas energi lebih rendah daripada remaja obesitas. ${ }^{23}$ Makanan dengan densitas energi rendah dapat membantu seseorang menurunkan asupan energi, menciptakan rasa puas, dan dapat mengontrol rasa lapar. Sedangkan makanan dengan densitas energi tinggi memberikan rasa lezat gurih, renyah dan tinggi lemak, sehingga konsumsi makanan dengan densitas energi tinggi secara berlebihan berkontribusi dalam peningkatan asupan energi total yang dapat mempengaruhi berat badan dan berakibat pada peningkatan Indeks Massa Tubuh (IMT). ${ }^{13,26}$

Selain dipengaruhi asupan makanan, IMT secara langsung dapat dipengaruhi oleh aktifitas fisik. Namun, dalam penelitian ini aktifitas fisik tidak mempengaruhi nilai IMT. Penilaian status gizi yang diukur dengan IMT dapat dipengaruhi oleh asupan makan dan aktifitas fisik atau kombinasi keduanya. Dalam penelitian ini status gizi lebih dipengaruhi oleh asupan makanan. Keseimbangan energi antara asupan makanan yang masuk dengan pengeluaran energi juga akan mempengaruhi berat badan. Apabila asupan energi yang masuk sama dengan energi yang dikeluarkan untuk aktifitas fisik, maka tidak terjadi kelebihan asupan energi yang disimpan dalam bentuk lemak dan mempengaruhi berta badan. Apabila pemasukan energi lebih kecil dari pengeluaran energi maka akan terjadi keseimbangan negatif, sehingga cadangan makanan dikeluarkan, hal ini berakibat pada penurunan berat badan. Sebaliknya, apabila pemasukan energi lebih banyak dari pengeluaran energi maka terjadi keseimbangan positif, kelebihan energi akan disimpan dalam tubuh sehingga terjadi peningkatan berat badan. ${ }^{27}$

\section{SIMPULAN}

Remaja yang mengkonsumsi lebih banyak makanan berdensitas energi rendah (buah dan sayur) kualitas dietnya lebih baik dan IMT nya lebih rendah daripada remaja yang mengkonsumsi makanan berdensitas energi tinggi (sumber lemak). Kualitas diet rendah berhubungan dengan tingginya konsumsi makanan berdensitas energi tinggi yang dapat berdampak pada peningkatan IMT.

\section{SARAN}

Perlunya mengkonsumsi makanan sesuai dengan rekomendasi diet yang dianjurkan untuk mencapai kualitas diet yang baik pada remaja. Kualitas diet yang baik salah satunya ditunjukkan dengan meningkatkan konsumsi makanan berdensitas energi rendah seperti sumber serat 
(sayur dan buah) dan membatasi sumber makanan berdensitas energi tinggi (makanan yang digoreng, daging, es krim, dan fast food) untuk mencapai status gizi yang optimal.

\section{UCAPAN TERIMAKASIH}

Penulis mengucapkan terima kasih kepada subjek penelitian dan semua pihak yang telah membantu dalam penyusunan karya tulis ilmiah ini. Terima kasih penulis sampaikan pula kepada Fillah Fithra Dieny,S.Gz, M.Si selaku pembimbing dan para reviewer, Prof. Dr. H.M. Sulchan, MSc, DA. Nutr., Sp.GK dan Nurmasari, S.Gz, M.Si atas kritik dan saran yang diberikan.

\section{DAFTAR PUSTAKA}

1. Hariyani Sulistyoningsih, Gizi Untuk Kesehatan Ibu dan Anak, Yogyakarta : Graha Ilmu; 2011. Hal 26-35.

2. Suandi. Gizi Pada Masa Remaja. Dalam : Soetjiningsih, Tumbuh Kembang Remaja dan Permasalahannya, Jakarta: Sagung Seto. Hal 15.

3. Helmut Schroder, Montserrat Fito and Maria Isabel. Association of fast food consumption with energy intake, diet quality, body mass index and the risk of obesity in a representative Mediterranean population. British Journal of Nutrition. 2007; 98: 1274-80.

4. Riset Kesehatan Dasar 2007. Badan Penelitian dan Pengembangan Kesehatan. Departemen Kesehatan Republik Indonesia.

5. Riset Kesehatan Dasar 2010. Badan Penelitian dan Pengembangan Kesehatan. Departemen Kesehatan Republik Indonesia.

6. Dolores $\mathrm{M}$, et al. Diet quality and obesity in women: the FraminghamNutrition Studies. British Journal of Nutrition . 2010; 103: 1223-29.

7. Nutrition transition among adolescents of a South-Mediterranean Country: Dietary Patterns, Association With Socio-economic Factors, Overweight and Blood Pressure. A CrossSectional Study in Tunisia. Nutrition Journal 2011; 24:10-38.

8. Mehmet Akman, et al. Eating Patterns of Turkish Adolescents: a Cross-Sectional Survey. Nutrition Journal 2011; 9: 67.

9. Family Nutrition Programs. Diet Quality of Americans by Food StampParticipation Status:Data from the National Health and Nutrition Examination Survey, 1999-2004. United States Food and Department of Nutrition Agriculture Service, July 2008.

10. E Patterson et al. Dietary energy density as a marker of dietary quality in Swedish children and adolescents : the European Youth Heart Study. European Journal of Clinical Nutrition 2010, 1-8.

11. Ashima K Kant et al. Association of breakfast energy density with diet quality and body mass index in American adults: National Health and Nutrition Examination Surveys, 1999-2004. Am J Clin Nutr 2008; 88:1396-404.

12. H Schroder, et al. Diet quality and lifestyle associated with free selected low-energy density diets in a representative. Spanish population European Journal of Clinical Nutrition 2008; 62: 1194-1200.

13. Howarth NC, et al. Dietary energy density is associated with overweight status among 5 ethnic groups in the multiethnic cohort study. J Nutr 2006; 136: 2243-48.

14. Stang J and Story M. Understanding Adolescent Eating Behavior. Departement of Health and Human Services:US; 2005.p.1-15;101-102;55.

15. World Health Organization. Growth References 5-19 years for adolescence. Diunduh dari http://www.who.int//growthreferences5-19 yearsforadolescence2007-pdf// diakses pada tanggal 5 Mei 2012.

16. Ledikwe JH, et al. Dietary energy density is associated with energy intake and weight status in US adults. Am J Clin Nutr 2006a; 83: 1362-1368.

17. Soowon Kim, et al. The Diet Quality IndexInternational (DQI) Provides an Effective Tool for Crosse-National Comparison of Diet Quality as Illustrated by China and The United States. J.Nutr 2003; 133: 3476-3484.

18. Guidelines for Data Processing and Analysis of the International Physical Activity Questionnaire (IPAQ)- Short and Long Forms. November 2005. Diunduh dari http://www.ncbi.nlm.nih.gov/pmc/articles/PMC27 44347/ diakses pada tanggal 18 April 2013.

19. Wiwied Dwi Oktaviani dkk. Hubungan Kebiasaan Konsumsi Fast Food, Aktivitas Fisik, Pola Konsumsi, Karakteristik Remaja Dan Orang Tua Dengan Indeks Massa Tubuh (IMT) (Studi Kasus Pada Siswa Sma Negeri 9 Semarang Tahun 2012). Jurnal Kesehatan Masyarakat 2012; 1: 542 $-553$.

20. L. Kathleen Mahan and Sylvia Escott-Stump. Krause' Food and Nutrition Therapy. USA. Edition 12. 2008. Hal: 246-254.

21. Grunwald GK, Seagle HM, Peters JC, Hill JO. Quantifying and separating the effects of macronutrient composition and nonmacronutrients on energy density. $\mathrm{Br} \mathbf{J}$ Nutr 2001;86:265-76.

22. Kant AK, Graubard BI: Energy density of diets reported by Americans adults: association with food group intake, nutrient intake, and body weight. Int $\mathbf{J}$ Obes Relat Metab Disord 2005;29:950-956.

23. Maillot $\mathrm{M}$, et al. Low energy density and high nutritional quality are each associated with higher diet costs in French adults. Am J Clin Nutr. 2007 ; 86: 690-696. 
24. National Center for Chronic Disease Prevention and Health Promotion Division of Nutrition and Physical Activity. Can eating fruits and vegetables help people to manage their weight? 2011.

25. Nadia Gharib, Parveen Rasheed. Energy and Macronutrient Intake and Dietary Pattern Among School Children in Bahrain: a Cross-Sectional Study. Nutrition Journal 2011. At http//www.nutritionj.com Diakses pada tanggal 15 November 2011

26. Mendoza JA, Drewnowski A, Christakis DA. Dietary energy density is associated with obesity and the metabolic syndrome in US adults. Diabetes Care 2007; 30: 974-979.

27. National Heart, Lung, and Blood Institute. Balance Food and Activity. [serial online] 2013 Feb 13 [cited 2013 Aug 01];1p. Available from: URL:

HYPERLINK.http://www.nhlbi.nih.gov/health/pu blic/heart/obesity/wecan/healthy-weightbasics/balance.htm 